\title{
Pharmacognostic and Cytotoxicity Evaluation of Indonesia Native Plant of Piper acre Blume Leaves (Piperaceae)
}

\author{
Islamudin Ahmad ${ }^{1,3}$, Neneng Silfi Siti Ambarwati2,3, Muhammad Arifuddin' ${ }^{2}$, Laode Rijai' , Abdul Mun'im ${ }^{3}$
}

\section{Islamudin Ahmad ${ }^{1,3}$, Neneng Silfi Siti Ambarwati ${ }^{2,3}$, Muhammad Arifuddin', Laode Rijai' , Abdul Mun'im ${ }^{3}$ \\ 'Department of Pharmaceutical Scienc- es, Faculty of Pharmacy, Mulawarman University, Samarinda, East Kalimantan, INDONESIA. \\ ${ }^{2}$ Department of Health and Beauty, Faculty of Engineering, Jakarta State University, Jakarta, INDONESIA. ${ }^{3}$ Departement of Pharmaceutical Sci- ences, Faculty of Pharmacy, Univer- sitas Indonesia, Depok, West Java, INDONESIA.}

\section{Correspondence}

Islamudin Ahmad,

Kampus UI Depok-West Java 16424, INDONESIA.

Phone no: +6281342205060

E-mail: islamudinahmad@farmasi.unmul. ac.id

History

- Submission Date: 16-12-16.

- Review completed: 05-01-17;

- Accepted Date: 27-02-17.

DOI : 10.5530/pj.2017.3.68

Article Available online

http://www.phcogj.com/v9/i3

\section{Copyright}

(C) 2017 Phcog.Net. This is an openaccess article distributed under the terms of the Creative Commons Attribution 4.0 International license.

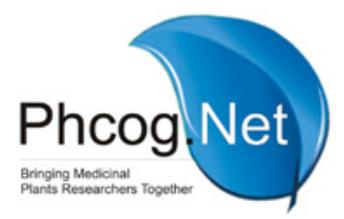

\begin{abstract}
Piper acre Blume (Piperaceae) is an Indonesia native plant that is used as a traditional medicine and commonly known as 'Sirih Hitam' or 'Sirih Hutan'. The scientific data from the plant is still very limited. The aims of the present study was to know a pharmacognostic, and cytotoxicity of $P$. acre Blume leaf. The macroscopic characters showed that the leaves have a characteristic odor, heart-shaped, margin was finely flat, venation was curved, the upper surface was dark green and slippery while the lower surface was pale green and soft. The microscopic characters revealed upper and lower epidermis cells, glandular trichomes, concentric vascular bundle, paracytic stomata. The fluorescence characteristics showed a variety of chemical constituents present in the plant materials. The preliminary phytochemical investigation of various extracts showed the presence of alkaloid, flavonoid, saponin, terpenoid, tannin, carotenoid, and steroid. The physicochemical properties (yield, color, consistency) of the $\mathrm{n}$-hexane, ethyl acetate, and ethanol extract were $31.57 \% \mathrm{w} / \mathrm{w}$ (green concentrated solid), 13,59\% $\mathrm{w} / \mathrm{w}$ (green concentrated solid), and $16.35 \% \mathrm{w} / \mathrm{w}$ (brownish green liquid). Based on the cytotoxicity using brine shrimp lethality assay of the $\mathrm{n}$-hexane extract $(2.46 \mu \mathrm{g} / \mathrm{ml})$, ethyl acetate extract $(0.925 \mu \mathrm{g} / \mathrm{ml})$, and ethanol extract $(5.741 \mu \mathrm{g} / \mathrm{ml})$ showed that the extract had the cytotoxic activity.
\end{abstract}

Key words: Piper acre Blume, pharmacognostic, preliminary phytochemical, physicochemical, cytotoxicity.

\section{INTRODUCTION}

The genus of Piper has more than 1,000 species, which is one of the most diverse genera of the shrubs, herbs, and Liana commonly found in the lowland wet forest. The diversity of the genus occurs in Tropical America (700 species) and South Asia (300 species). ${ }^{1,2}$

Empirically, the species from the genus of Piper had been widely used in traditional medicine such as $P$. betle, $P$. nigrum, $P$. piscatorum, $P$. dariensis, $P$. longum, $P$. auritum, $P$. sarmentosum, $P$. amalago and many other species. Researchers had reported some activities of these plants, such as anesthetic, antiinflammatory, analgesic, antibacterial, antidepressant, antioxidant, and anticancer. ${ }^{3-6}$ Phytochemical investigations from many species of Piper had isolated biologically active compounds including lignans, alkaloids, flavones, aristolactams, unsaturated amides, monoterpenes, long and short chain esters, sesquiterpenes, arylpropanoids, aldehydes, ketones, propenylphenols, and chalcones. ${ }^{7}$ Until now, there are still many other species that has not examined, one of which is Piper acre Blume.

$P$. acre Blume is an Indonesian native plant that used as a traditional medicine and commonly known as 'Sirih Hitam' or 'Sirih Hutan' with spread growth in Java Island and East Kalimantan. Empirically, this plant used as a traditional medicine for various diseases by Indonesian (a particularly local community in East Kalimantan), such as itching due to infection, cysts, prostate, pain (abdominal pain), and jaundice.
However, the scientific data is still very limited. This plant had been conducted toxicity tests using animal models. The test results showed that the water extract of $P$. acre Blume proved not caused liver necrosis based on changes levels of SGPT and SGOT ${ }^{8}$ and also had reported antioxidant activity using the DPPH (1,1-diphenyl-2-picrylhydrazyl) radical scavenging method. ${ }^{9}$ Therefore, it becomes more interesting to explore pharmacognostic profile of this plant. The pharmacognostic study related to authentication, standardization, and natural products study.

\section{MATERIALS AND METHOD}

\section{Plant Collection and Authentication}

Leaves of Piper acre Blume (P. acre Blume) were collected from Samarinda, East Kalimantan, Indonesia. Moreover, this plant was identified at Laboratory of Biosystematics, Indonesian Institute of Science (LIPI) - Cibinong, West Java, Indonesia. Moreover, the voucher specimen was deposited at Laboratory of Research \& Development of FARMAKA TROPIS, Mulawarman University.

\section{Macroscopic Evaluation}

Macroscopic evaluation of $P$. acre Blume leaves based on the method in some literature. ${ }^{10-12}$ Fresh, dried, and powder of leaves sample was observed by organoleptic (shape, size, color, and odor). 


\section{Microscopic Evaluation of Fresh Leaf and Dried Powder}

Transversal and longitudinal sections of the fresh leaves prepared using the standard procedures. ${ }^{10,13-15}$ Both sections were observed under microscope Nikon Eclipse E200 (10X and 40X), photomicrographs of specimens were taken using Nikon Coolpix 4500 camera (4,0 megapixel). Dried leaves powder was carried out using the chloral hydrate and phloroglucinol-HCl reagent, and also was observed under microscope Nikon Eclipse E200 (10X and 40X), photomicrographs of specimens were taken using Nikon Coolpix 4500 camera (4,0 megapixel).

\section{Fluorescence Evaluation}

Fluorescence study of the dried leaves powder performed using standard procedure. ${ }^{11,12,16} \mathrm{~A}$ small quantity of the sample treated using fluorescence reagents (such as $1 \mathrm{~N} \mathrm{NaOH}, 1 \mathrm{~N} \mathrm{HCl}, 50 \% \mathrm{H}_{2} \mathrm{SO}_{4}, \mathrm{FeCl}_{3}$, Iodine solution, Acetic Acid Glacial, 0,1 N NH $\mathrm{NH}_{4} \mathrm{OH}$ \% $\mathrm{CH}_{3} \mathrm{COOH}$ ). Moreover, analyzed under visible light, short ultra-violet light (wavelength 254 $\mathrm{nm}$ ), and long ultra-violet light (wavelength $366 \mathrm{~nm}$ ).

\section{Preliminary Phytochemical Evaluation}

The dried leaves powder were macerated successively with different solvent (n-hexane, ethyl acetate, and ethanol). ${ }^{17,18}$ The sample was macerated successively with n-hexane, ethyl acetate, and n-butanol for 24 hours. Extracts solution was evaporated to obtain dried extracts and analyzed using chemical reagent for preliminary phytochemical investigation of various groups of phytoconstituents such as alkaloids, flavonoids, saponins, terpenoids, tannins, carotenoids, and steroids by using the standard procedure.

\section{Physicochemical Evaluation}

This study was just using physicochemical parameters like percentage yield (\% w/w), color and consistency of the extracts. ${ }^{12}$

\section{Cytotoxicity Evaluation}

The cytotocicity evaluation was performed using brine shrimp lethality test (BSLT) assay according to the method describe in the literature with modification. ${ }^{19-21}$ Each of the extracts was tested at 40, 20, 10, 5, 2.5, 1.25 , and $0.75 \mu \mathrm{g}$ of extract per $\mathrm{ml}$ (in seawater). The concentration was achieved by transferring the appropriate volume from the stock solution; it performed by inserting ten brine shrimp aged $48 \mathrm{hr}$ (mainly nauplii in instar III/IV) into the vessels containing the test solution extracts and incubated at $28-30^{\circ} \mathrm{C}$ with strong aeration, under a continuous light regime. Moreover, the number of survivors counted and calculated, and then analyzed using a statistical method (regression linearity) to determine $\mathrm{LC}_{50}$.

\section{RESULTS}

\section{Authentication and macroscopic evaluation}

The classification of this plant through the process of identification at the Indonesian Institute of Sciences (LIPI) - Cibinong, West Java, Indonesia, and according to Cronquist ${ }^{22}$ as follows:

Family : Piperaceae

Genus : Piper

Species : Piper acre Blume.

Fresh leaves of $P$. acre Blume was dark green. The leaves is simple, have a characteristic odor and its heart-shaped with average leaf size is $4.5-8$ cm length and 3-6 cm breadth. Apex (Apex folii) tends to taper (acuminate). Base (basis folii) is notched (emerginatus), the margin is finely flat, venation was curved like lines curved, the upper surface is dark green and smooth while the lower surface is pale green and soft, and also dried leaves is blackish green. Authentication and macroscopic characteristics of the leaves shown in Figure 1A.

\section{Microscopic evaluation of the fresh and dried powder}

Photomicrographs of the fresh of $P$. acre Blume leaf showed in Figure 1B. The transverse section revealed that the cells of lower epidermal cells were comparatively larger than the upper one, the reason is that the lower epidermis cells have many glandular epidermal hair (glandular trichomes) with contained oil glands. A single layer of cuticle covered the epidermis cells. About 4-6 layers of cortex (spongy mesophyll cells) surrounded the concentric vascular bundle wich the cortex consists of spherical shaped parenchymatous cells. The longitudinal section of the leaves presenting stomata on adaxial only (Hypostomatic leaf) with the paracytic types.

The most common features from the leaves' powder were stomata with paracytic types, spiral vessels element, oil glands with reddish yellow colors, and glandular trichomes (Figure 3C). This characteristic was observed and reported for the first time report.

\section{Fluorescences evaluation}

The fluorescences characteristics of the dried leaves powder analyzed under visible light, short ultra-violet, long ultra-violet after treatment with organic and inorganic reagents (summarized in Table 1). Fluorescence is a characteristic shown by a variety of chemical constituents present in the plant materials. The chemical constituents that had been treated using different reagents would fluoresce at a specific wavelength especially in visible light, short ultra-violet light (254 $\mathrm{nm}$ wavelength), and long ultra-violet light (366 nm wavelength).

\section{Physicochemical evaluation}

The physicochemical evaluation using percentage yield $(\% \mathrm{w} / \mathrm{w})$, color and consistency parameters of the extracts. The percentage yield successive highs on n-hexane, ethanol, and ethyl acetate extracts, wherein the n-hexane extract was nonpolar and contains much chlorophyll, the ethyl acetate extract possibilities are only a few chlorophyll. However, the extract can attract the compound types that vary especially the compound groups which have moderate polarity. While on the ethanol extract that can attract polar compounds. The percentage yield $(\% \mathrm{w} / \mathrm{w})$ with color and consistency, mentioned in Table 2.

\section{Preliminary phytochemical evaluation}

The preliminary phytochemical investigation of the extracts showed the presence of chemical constituents from each extract based on different polarity levels of solvents (n-hexane, ethyl acetate, and ethanol). N-hexane extract showed the presence of flavonoids, terpenoids, carotenoids, and steroids. Ethyl acetate extract showed the presence of alkaloids, flavonoids, saponins, terpenoid, carotenoids, and steroids, and Ethanol extract showed the presence alkaloid, saponins, tannins, carotenoids, and steroids, mentioned in Table 3.

\section{Cytotoxicity valuation}

The cytotoxicity evaluation using Brine Shrimp Lethality Test (BSLT), the $\mathrm{LC}_{50}$ was obtained with n-hexane, ethyl acetate, and ethanolic extracts (showed in Table 4). The results achieved in the present study indicate the cytotoxic activities found in each extract, and the most powerful was the ethyl acetate extract $\left(\mathrm{LC}_{50}=0.925 \mu \mathrm{g} / \mathrm{ml}\right)$. Although, all of them were categorized as cytotoxic agent (each $\mathrm{LC}_{50}$ values of less than $30 \mu \mathrm{g}$ / $\mathrm{ml}$ was considered cytotoxic). ${ }^{8,21}$ 


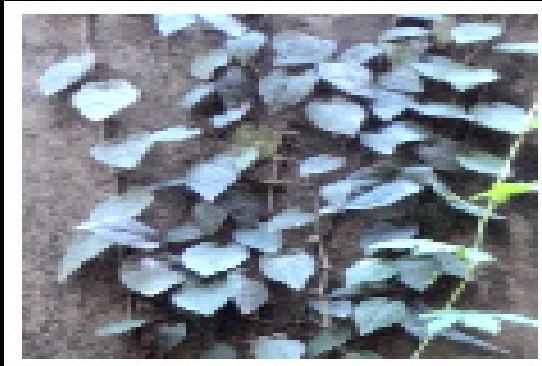

A1

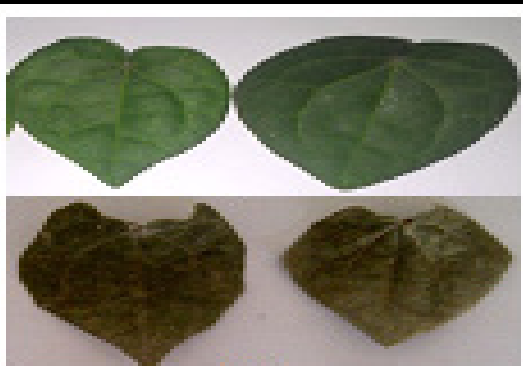

A2

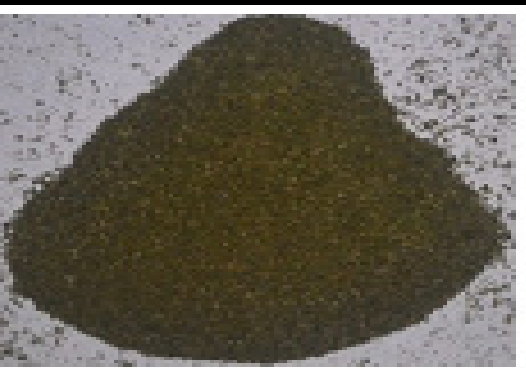

A3

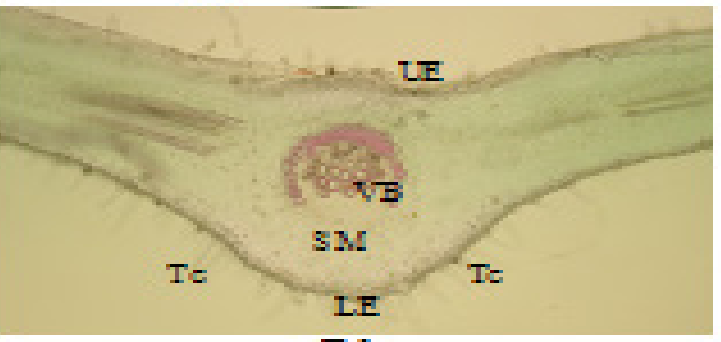

B1

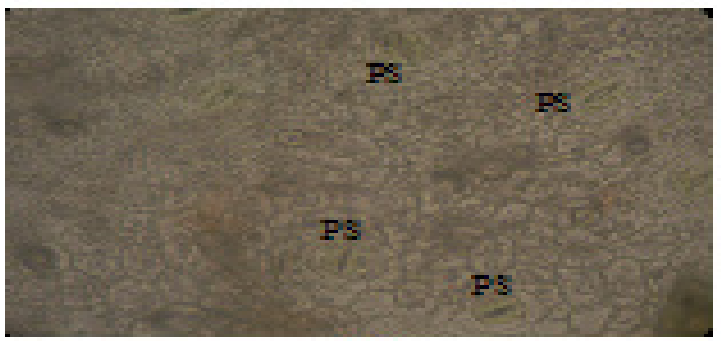

B2

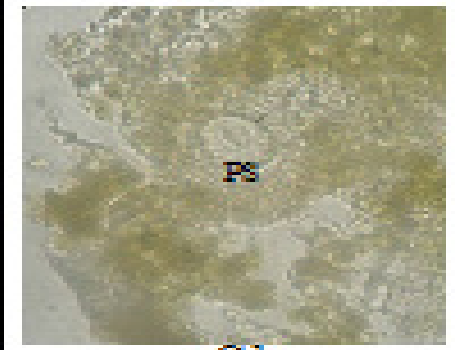

$\mathrm{C} 1$

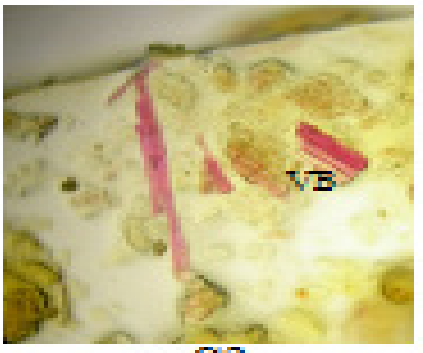

$\mathrm{C2}$

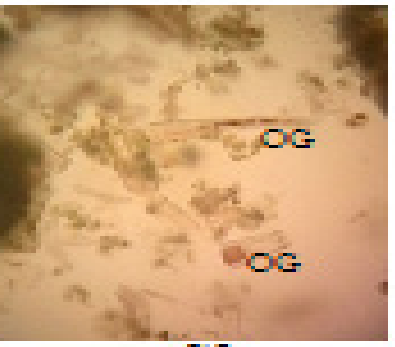

$\mathrm{CB}$

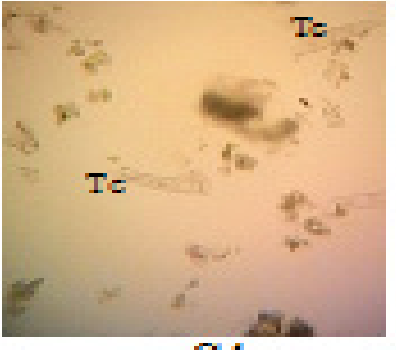

$\mathrm{C} 4$

Figure 1: Macroscopic and Microscopic characteristics of Piper acre BLUME.

Where; (A1) Piper acre Blume in natural habitat; (A2) a part showing the fresh and dried leaf; (A3) dried leaf powder; (B1) Transversal and (B2) longitudinal sections of the fresh leaf, (C) dried leaf powder; (UE) upper epidermis; (VB) vascular bundle; (Tc) Trichome; (SM) spongy mesophyll cell; (LE) lower epidermis; (PS) paracytic stomata; and (OG) oil glands.

Table 1: Fluorescence Characteristics of Dried Leaves Powder of Piper Acre Blume

\begin{tabular}{|c|c|c|c|}
\hline Powder + Reagent & $\begin{array}{l}\text { Colour Observed } \\
\text { in Ordinary light }\end{array}$ & $\begin{array}{l}\text { Colour Observed } \\
\text { Under UV Short } \\
(254 \mathrm{~nm})\end{array}$ & $\begin{array}{l}\text { Colour Observed } \\
\text { Under UV long } \\
(366 \mathrm{~nm})\end{array}$ \\
\hline Powder as such & Yellowish green & Yellowish green & Yellowish green \\
\hline $\begin{array}{c}\text { Powder }+1 \mathrm{~N} \mathrm{NaOH} \\
\text { in water }\end{array}$ & Yellowish green & Brownish black & Greenish black \\
\hline Powder $+1 \mathrm{~N} \mathrm{HCl}$ & Brownish green & Brownish green & Greenish black \\
\hline Powder $+50 \% \mathrm{H}_{2} \mathrm{SO}_{4}$ & Brownish black & Reddish black & Greenish black \\
\hline Powder $+\mathrm{FeCl}_{3}$ & Greenish black & Greenish black & Greenish black \\
\hline Powder + Iodine water & Reddish black & Reddish black & Greenish black \\
\hline $\begin{array}{c}\text { Powder + Acetic Acid } \\
\text { Glacial }\end{array}$ & Yellowish green & Greenish black & Greenish black \\
\hline $\begin{array}{c}\text { Powder }+0.1 \mathrm{~N} \\
\mathrm{NH}_{4} \mathrm{OH}\end{array}$ & Brownish black & Brownish black & Greenish black \\
\hline $\begin{array}{c}\text { Powder }+1 \% \\
\mathrm{CH}_{3} \mathrm{COOH}\end{array}$ & Brownish black & Brownish black & Greenish black \\
\hline
\end{tabular}


Table 2: Nature and Percentage Yield of the Different Extracts of Dried Powdered Leaves of Piper acre Blume

\begin{tabular}{ccc}
\hline Extracts & Colour \& consistency of extract & $\begin{array}{c}\text { Percentage } \\
\text { Yield }(\% \mathrm{w} / \mathrm{w})\end{array}$ \\
\hline n-Hexane & Green concentrated solid & 31.57 \\
Ethyl acetate & Green concentrated solid & 13.59 \\
Ethanol & Brownish green liquid & 16.35 \\
\hline
\end{tabular}

Table 3: Preliminary Phytochemical Investigation Performed in the Various Extracts Dried Leaves Powder of Piper Acre Blume

\begin{tabular}{cccc}
\hline Phytochemical Test & $\mathrm{N}$-Hexane & Ethyl acetate & Ethanol \\
\hline Alkaloids & - & + & + \\
Flavanoids & + & + & - \\
Saponins & - & + & + \\
Terpenoids & + & + & - \\
Tannins & - & - & + \\
Carotenoids & + & + & + \\
Steroids & + & + & + \\
\hline
\end{tabular}

Note: + (Present), - (Absent)

Table 4: Cytotoxic Activity Evaluation Using Brine Shrimp Lethality Test (Bsit)

\begin{tabular}{cc}
\hline Extracts & $\begin{array}{c}\text { Lethal Concentration }(50 \%) \\
(\mu \mathrm{g} / \mathrm{ml})\end{array}$ \\
\hline n-Hexane & 2.460 \\
Ethyl acetate & 0.925 \\
Ethanol & 5.741 \\
\hline
\end{tabular}

\section{DISCUSSION}

Based on the history of pharmacognosy sciences, plants have used in traditional medicine systems throughout the world. Research on medicinal plants is rapidly increasing on a global level. Further study with emphasis on efficacy, safety, and quality of natural products in health care system. The pharmacognostic analysis has an important role in the authentication and standardization of a medicinal plant because it is a necessary step for herbal drugs and their formulation in the traditional system of medicine. ${ }^{23,24}$ The pharmacognostic character of crude extract is an initial information in standardization to maintain the purity, quality, and efficacy of crude drugs. ${ }^{18}$ Authentication and macroscopic evaluation are helpful to ensure the authenticity of crude drugs to evaluate the external appearance including the size, shape, color, taste, texture, smell, and so on. Microscopic evaluation of the fresh leaf sample is necessary for photomicrographs identification of microscopic characteristics (particularly types of stomata, vessels element, oil glands, and glandular trichomes) wich can distinguish with other species using optical microscopy. While, identifying the dried powder is useful for microscopical authentication based on the characteristics of the fresh sample. Fluorescence evaluation is an important parameter that most frequently used and assessed qualitatively for pharmacognostic evaluation of crude drugs. The physicochemical evaluation using percentage yield $(\% \mathrm{w} / \mathrm{w})$, color and consistency parameters is useful in the identification and authentication of crude extract. Preliminary phytochemical evaluation will express the chemical contents of each extract. Also, the activity evaluation will reveal the potential of active chemical constituents in each extract.
In the present work is preliminary data (specifically pharmacognostic and cytotoxic activity data) for further studies. Moreover, this data was first time reported from this plant. In addition to assist in establishing parameters for identification of raw materials and preparation of plant monograph but also will help in the development of future studies.

\section{CONCLUSION}

The results of this study are preliminary data for future studies and serves as a pharmacognostic parameter. This parameter was first time reported from this plant. In addition to assist in establishing parameters for identification of raw materials and preparation of plant monograph but also will help in the development of future studies.

\section{ACKNOWLEDGEMENT}

The author is thankful to Head Pharmaceutical Research \& Development Laboratory of FARMAKA TROPIS, Mulawarman University, and Head Laboratory of Pharmacognosy and Phytochemistry of Pharmacy Faculty, Universitas Indonesia for providing facilities, and also many thanks to Dean Pharmacy Faculty of Mulawarman University for financially supporting the study.

\section{CONFLICT OF INTEREST}

We declare that we have no conflict of interest

\section{ABBREVIATIONS USED}

SGPT: Serum Glutamic Pyruvate Transaminase; SGOT: Serum Glutamic Oxaloacetic Transaminase; DPPH: 1,1-diphenyl-2-picrylhydrazyl; LIPI: Lembaga Ilmu Pengetahuan Indonesia; BSLT: Brine Shrimp Lethality Test; LC $_{50}$ : Lethal Concentration-50; UE: upper epidermis; VB: vascular bundle; Tc: Trichome; SM: Spongy Mesophyll cell; LE: Lower Epidermis; PS: Paracityc Stomata; and OG: Oil Glands.

\section{REFERENCES}

1. Soltis PS, Soltis DE, Chase MW. Angiosperm phylogeny inferred from multiple genes as a tool for comparative biology. Nature. 1999;402(6760):402-4. https:// doi.org/10.1038/46528 PMid:10586878.

2. Jaramillo MA, Manos PS. Phylogeny and patterns of floral diversity in the genus Piper (Piperaceae). Am J Bot. 2001;88(4):706-16. https://doi. org/10.2307/2657072

3. Zakaria ZA, Patahuddin H, Mohamad AS, Israf DA, Sulaiman MR. In vivo anti-nociceptive and anti-inflammatory activities of the aqueous extract of the leaves of Piper sarmentosum. J Ethnopharmacol. 2010;128(1):42-8. doi:10.1016/j. jep.2009.12.021. https://doi.org/10.1016/j.jep.2009.12.021.

4. Tasleem F, Azhar I, Ali SN, Perveen S, Mahmood ZA. Analgesic and anti-inflammatory activities of Piper nigrum L. Asian Pac J Trop Med. 2014;7(1):4618. doi:10.1016/S1995-7645(14)60275-3. https://doi.org/10.1016/S19957645(14)60275-3.

5. Saha S, Verma RJ. In vitro and in silico study of Piper nigrum on cyclooxygenase-2, inducible nitric oxide synthase and antioxidant enzymes. J Herb Med. 2014;5(2):86-98. doi:10.1016/j.hermed.2015.01.005. https://doi.org/10.1016/j. hermed.2015.01.005.

6. Agbor GA, Vinson JA, Sortino J, Johnson R. Antioxidant and anti-atherogenic activities of three Piper species on atherogenic diet fed hamsters. Exp Toxicol Pathol. 2012;64(4):387-91. doi:10.1016/j.etp.2010.10.003. https://doi. org/10.1016/j.etp.2010.10.003.

7. Parmar VS, Jain SC, Bisht KS, Jain R, Taneja P, Jha A, et al. Phytochemistry of the Genus Piper. Phytochemistry. 1997;46(4):597-673. http://www5e.biglobe. ne.jp/lycoris/img062-general.karyomorph.lycoris.pdf. https://doi.org/10.1016/ S0031-9422(97)00328-2.

8. Rijai L, Kuncoro H, Herman. Forest betel ( $P$. acre Blume) a wild plant from East Kalimantan, Indonesia potentially as resources of drug compounds for cancer. J Pharm Sci Res. 2015;7(7):401-4. http://www.jpsr.pharmainfo.in/issue. php?page $=71$.

9. Rija'i HR, Syafnir L, Rismawati E. Antioxidant activity of Sirih Hitam (Piper acre Blume.) using free radical scavenger DPPH (1,1-difenil-2-pikril hidrazil). In: Prosiding Farmasi SPeSIA 2015. Bandung: Universitas Islam Bandung; 2015:58-64. (In Bahasa)

10. Khan AA, Bhatnagar SP, Sinha BN, Lal UR. Pharmacognostic specifications 
of eight cultivars of Piper betle from eastern region of India. Pharmacogn J. 2013;5(4):176-83. doi:10.1016/j.phcgj.2013.07.002. https://doi.org/10.1016/j. phcgj.2013.07.002

11. Kumar D, Kumar A, Prakash O. Pharmacognostic evaluation of stem bark of Pongamia pinnata (L.) Pierre. Asian Pac J Trop Biomed. 2012;2(2):543546. doi:10.1016/S2221-1691(12)60270-6. https://doi.org/10.1016/S2221 $1691(12) 60270-6$.

12. Kumar S, Natarajan B, Kanakamma LP, Ashish TF, Pawar RS. Pharmacognostical and Phytochemical evaluation of Ventilago calyculata Tul. (Bark). Pharmacogn J. 2015;7(5):271-5. doi:10.5530/pj.2015.5.3. https://doi.org/10.5530/pj.2015.5.3.

13. Shah B, Seth AK. Textbook of Pharmacognosy and Phytochemistry. (Nimisha Goswami, Subodh K. Chauhan, eds.). New Delhi: Published by Elsevier, a division of Reed Elsevier India Private Limited; 2010.

14. Ghori VP, Gatecha HN, Desai TR, Pandya DJ. Pharmacognostic study of leaves of Cordia rothii Linn. Pharmacogn J. 2011;3(22):35-8. doi:10.5530/pj.2011.22.7. https://doi.org/10.5530/pj.2011.22.7.

15. Suresh J, Ahuja J, Paramakrishnan N. Pharmacognostical investigation of Artemisia parviflora Roxb. Asian Pac J Trop Biomed. 2012;2(2):532-5. doi:10.1016/ S2221-1691(12)60267-6. https://doi.org/10.1016/S2221-1691(12)60267-6.

16. Sonibare MA, Olatubosun OV. Pharmacognostic and free radical scavenging Evaluation of Cyathula prostata (Blume) L. Pharmacogn J. 2015;7(2):107-16. doi:10.5530/pj.2015.2.5. https://doi.org/10.5530/pj.2015.2.5.

17. Ahmad I, Arifuddin M, Rijai L. The effect of extraction methods of Bawang Dayak (Eleutherine palmifolia L. MERR) against TLC profiles and sunscreen activi- ties. Int J PharmTech Res. 2016;9(9):428-36.

18. Ullah R, Ibrar M, Hameed I, Hussain F. Pharmacognostic and Pharmacological evaluation of Ruellia tuberosa L. Pak J Pharm Sci. 2016;29(6):2099-102.

19. Pervin R, Afrin S, Sabrin F Zohora US, Rahman MS, Islam KD, et al. Antioxidant, antibacterial and brine shrimp lethality bioassay of Amoora cucullata, a Mangrove plant. J Young Pharm. 2016;8(1):33-38. doi:10.5530/jyp.2016.1.8. https:// doi.org/10.5530/jyp.2016.1.8.

20. Ahmad I, Ibrahim A. Bioactivity of methanol extract and n-hexane fraction of Sungkai (Peronema canescens JACK) using brine shrimp lethality test. J Sains dan Kesehatan. 2015;1(3):90-5. (In Bahasa)

21. Carballo JL, Hernández-Inda ZL, Pérez P, García-Grávalos MD. A comparison between two brine shrimp assays to detect in vitro cytotoxicity in marine natural products. BMC Biotechnol. 2002;2:17. doi:10.1186/1472-6750-2-17. https://doi. org/10.1186/1472-6750-2-17

22. Cronquist A. An Integrated System of Classification of Flowering Plants. New York: Columbia University Press; 1981. PMid:6117027.

23. Menpara D, Chanda S. Phytochemical and pharmacognostic evaluation of leaves of Pongamia pinnata L. (Fabaceae). Pharmacogn Commun. 2014;4(2):37. doi:10.5530/pc.2014.2.2. https://doi.org/10.5530/pc.2014.2.2.

24. Mukherjee PK, Wahile A. Integrated approaches towards drug development from Ayurveda and other Indian system of medicines. J Ethnopharmacol. 2006;103(1):25-35. doi:10.1016/j.jep.2005.09.024. https://doi.org/10.1016/j. jep.2005.09.024.

\section{ABOUT AUTHORS

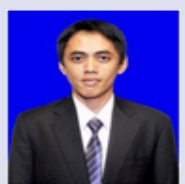 \\ Islamudin Ahmad, a doctoral student at Department of Pharmaceutical Sciences, Faculty of Pharmacy, Universitas Indonesia (UI) Depok, West Java, Indonesia, and also as a lecturer at Faculty of Pharmacy, Mulawarman University, Samarinda, East Kalimantan, Indonesia. The doctoral research focused on the study of screening activity and angiotensin converting enzyme (ACE) inhibitory active compound from the natural product for drugs discovery as antihypertension.}

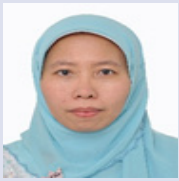

Neneng Siti Silfi Ambarwati, a doctoral student at Department of Pharmaceutical Sciences, Faculty of Pharmacy Universitas Indonesia, Depok, West Java, Indonesia. She also as a lecturer at Departement of Health and Beauty, Faculty of Engineering, Jakarta State University, Jakarta, Indonesia. The doctoral research focused on the isolation, identification, semi-synthetic of the active compound as antibacterial.

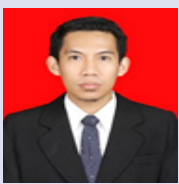

Muhammad Arifuddin, a Lecturer at Department of Pharmaceutical Sciences, Faculty of Pharmacy, Mulawarman University Samarinda, East Kalimantan, Indonesia. He has an interest in the natural product especially endofit fungi from plants.

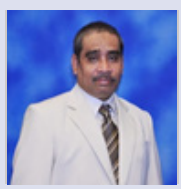

Dr. Laode Rijai, Associate Professor and Dean at Faculty of Pharmacy, Mulawarman University, Samarinda, East Kalimantan, Indonesia. He has experience in the area of Natural Product and Organic Chemistry.

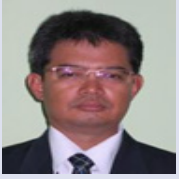

Dr. Abdul Mun'im, Associate Professor at Departement of Pharmaceutical Sciences, Faculty of Pharmacy, Universitas Indonesia (UI) Depok, West Java, Indonesia. He has experience in the area of Pharmacognosy and Phytochemistry, working in drugs discovery of herbal plants, extraction technology, Metabolite profiling, Structure Elucidation, and Degenerative Diseases (such as diabetes mellitus, antihypertension, and cholesterol).

Cite this Article: Ahmad I, Ambarwati NSS, Arifuddin M, Rijai L, Mun'im A. Pharmacognostic and Cytotoxicity Evaluation of Indonesia Native Plant of Piper acre Blume Leaves (Piperaceae). Pharmacogn J. 2017;9(3):400-4. 